\title{
God: A Brief History with a Cognitive Explanation of the Concept ${ }^{1}$
}

\author{
ILKKA PYYSIÄINEN \\ University of Helsinki
}

\begin{abstract}
The Christian concept of 'God' names a category with surprisingly heterogeneous contents. In the Old Testament traditions God is an anthropomorphic agent; in Christian theology God often appears as a personalized metaphysical principle; philosophers of religion try to find the inherent rationality of this concept; finally, some natural scientists regard God as the "intelligent designer" of the world. What is common to all these ideas, covering a time span of about 2,500 years, is that representations of God are triggered by the perception of order and control in the world.
\end{abstract}

\section{God Described}

We find the idea of God equally in ancient Israelite folk religion, Christian theology, modern philosophy of religion, and in the recent debates about the "intelligent design" that the world supposedly manifests. In what follows, I first present an overview of these four types of discourses. I then try to explain what holds them together as manifestations of the same basic idea. The theoretical background of this study is in the cognitive science of religion (Barrett 2000; Pyysiäinen 2004b; Pyysiäinen \& Anttonen 2002) and cognitive history (Martin 2004; in press; Whitehouse and Martin 2004).

\footnotetext{
${ }^{1}$ This article was written within a project funded by the Academy of Finland (\#200827).
} 


\section{Yahweh as god}

The fact that 'God' is at once the name of the god of Christianity and of the general category of gods has caused some confusion in the study of religion. What is it, in fact, that makes an entity a god? (see Pyysiäinen 1997; 2003a; Pyysiäinen \& Ketola 1999). Mark Smith (2001, 6-7) has recently taken up this question in connection with Semitic traditions, asking what is an ilu (Akkadian for ' god' $^{\prime}$ ) If we look for the answer by listing the various figures called "divine" in the Semitic languages (Akkadian ilu, Ugaritic 'il, Hebrew 'él), not only major deities come up but also such phenomena as monstrous cosmic enemies, demons, some living kings and dead kings, the dead in general, images of deities, and so forth. In addition, in Akkadian cuneiform writing special signs are used to indicate a determinative; one of these signs (transcribed as 'dingir') has the meaning that the word that follows is the name of a god (see Di Vito 1993, 74-120). This sign applies not only to names of deities proper but also to many other phenomena such as stars, images of monstrous creatures, heroes of old, and so forth. What is common to all divine beings is the fact that they are considered to be somehow greater than humans and yet somehow resemble humans.

Another strategy is to study the appellations of gods etymologically. Ilu, for example, is derived from *' $y / w l$, 'to be pre-eminent, strong.' (The English 'God' derives from the Indo-European ghu-, 'to call, invoke.') Yet the relationship between etymology and meaning is often a complex one and can easily be used to support conclusions that are not really warranted. A third approach is to compare Ugaritic and West Semitic sources in order to better understand the specific nature of the god of the Israelites (as in Smith 2002). As a fourth alternative Smith lists attempts to create typologies of gods on various grounds. In a recent volume he tries to combine all these approaches (Smith 2001, 6-8).

The Yahweh of the Israelites has often been regarded as somehow unique in being the god of an ethical and exclusive monotheism, in contrast to the polytheism and "nature religion" of the "Canaanites." This view does not receive much support from the historical evidence and the new analyses that 
have accumulated during the 1990's, as recognized by Smith (2002, xii-xli) in his preface to the second edition of his The early history of God. First, the origins of Yahweh are partly obscure; second, in any case, historical sources do not point towards any "original monotheism" (as once argued by Albright [1968]). Egyptian, Assyrian, and Babylonian inscriptions from the $9^{\text {th }}$ and $8^{\text {th }}$ centuries speak of the Yahweh of Samaria, the Yahweh of Teman, and the Yahweh who is the god of Jerusalem and of the whole country and to whom belong the mountains of Judah (Lauha 1997; see Smith 2001, 9-14). The figure of Yahweh may have originated at the southern sites of Seir/Edom/ Teman/Sinai, located in the northwestern Arabian peninsula east of the Red Sea, with the cult of Yahweh then being transplanted to highland sites such as Shiloh. However, these southern sites do not seem like a probable home for a god of storm and war, such as Yahweh. Evidence from Ugaritic texts, in fact, suggests that the figure of Yahweh may also derive from those of El and Baal; again, we do not know this with any certainty. All we can safely say is that Yahweh has a complex and partly unknown relationship with El (Smith 2001, 145-146; 2002, 19-31, 43-47).

It seems very probable that $\mathrm{El}$ was the original god of the Israelites. First, the name of this people contains the element *'él (Isra-el); if Yahweh had been the original God, then the name might have been *yiśrâ-yāh. When the name of Israel began to refer to the historical phenomenon of a people in the Iron I highlands (1100-950 вс), it perhaps no longer referred to the god to whom it was devoted. Second, Biblical texts (e.g., Genesis 49:24-25) attest to Yahweh and $\mathrm{El}$ as different gods sanctioned by early Israel. In the Septuagint, Deuteronomy 32:8-9, for instance, presents El (Elyon) as the chief god and Yahweh as one of his five sons (also 4QDeut in the Dead Sea Scrolls). Third, in Exodus 6:2-3 Yahweh says to Moses that he had previously appeared to the ancestors as El Shadday (Smith 2001, 142-143; 2002, 32-43).

The earliest gods in the world's religious traditions tend to be local in the sense that their identity is based either on a specific cultic practice, or on a specific inhabited place, from loosely bounded territories to towns (see Pyysiäinen 1997). Archaelogical and historical evidence, as well as cognitive 
theorizing, points to the conclusion that the earliest forms of religion cannot have been based on authorized doctrines about counterintuitive realities; it is rather a question of ritual practices without any standardized interpretation (Mithen 2004; Whitehouse 2000; 2004).

Goody (2000, 105-106) suggests that saints, ancestors and the like belong to oral religions, whereas god-beliefs of the monotheistic type belong to literate religions. This is because monotheism presupposes generalization and abstraction beyond specific contexts and concerns, aiming at universalistic claims. These, in turn, are made easier with the help of writing which decouples words and ideas from a particular context, creating the idea of fixed dictionary-meanings (see Pyysiäinen 2004b, 147-171; Person 1998; Smith 2002, xxiv, 191-193). Writing enables guilds of religious specialists to develop general truths that are meant for all (Boyer 2001, 278).

Monotheism appears as a theme in biblical texts dating to the sixth century $\mathrm{BC}$, representing an inner-Israelite development over hundreds of years (Smith 2002, 182-199; Gnuse 2000, 19-25). It is not a separate stage of religion in ancient Israel, but rather a form of rhetorical underscoring and reinforcing of Israel's exclusive relationship with its deity (Smith 2001, 9-14). The monotheistic discourse can be hypothesized to have developed in a process guided by reflective thinking, supported by the cultural institution of scribalism, as suggested by Smith (2001, 176-177, 295 n. 49). He argues that the remarkable absence of mythical elements in the later texts of the Old Testament, compared to West Semitic traditions, might be explained by the fact that the scribes responsible for the now extant biblical traditions either consciously censored older descriptions of Yahweh, or that the deletion was more like a secondary consequence of the literary processing of the traditions. Especially the Wisdom literature reflects the transformation of mythic imagery into narrative form. The legal and prophetic criticisms of the monolatrous (but not monotheistic) cult owes much to writing (Smith 2002, 191-193).

Writing, indeed, has been generally assumed to be an important aid to memory that contributes greatly to the emergence of systematic bodies 
of knowledge, such as theologies (Sperber 1996, 56-76; Pyysiäinen 2004b, 160-171; Goody 2000)2 ${ }^{2}$. We need not think of the scribes as mere copyists; they may have actively helped create a fixed version of the varying oral traditions (see Niditch 1996; Person 1998). This also means the transformation of an "imagistic," cult-based religion into a "doctrinal," idea-based one (see Whitehouse 2000; 2004). The idea of God was removed from its cultic context and developed as an idea important qua idea. Yahweh was no longer tied to specific places or a single social function.

Smith (2001, 143-145) suggests that Yahweh became the sole god of Israel in three overlapping stages of development. First, El was the original chief god. Then he became the head of an early Israelite pantheon, with Yahweh as its warrior-god. In the third phase, El and Yahweh were identified as a single god. The merger probably took place at different rates in different parts of Israel. Then El as a separate god gradually disappeared, with Yahweh incorporating his characteristics. The peculiar Israelite monotheism then emerged when it was declared that people should worship Yahweh alone and that other gods were really nothing. The period of late monarchy (ending in 539 вс) and exile seem to represent the period when this form of monotheism emerged (Smith 2001, 149-166). The present practice of Western believers and scholars of religion of speaking of a single 'God' would have been incomprehensible for the ancient Israelites (and possibly even to early Christians). They were not dealing with a universal category with only one member in it but rather with different kinds of beings with differing names (such as El and Yahweh).

The earliest strata in the Old Testament texts contain many similarities with conceptions of god in Ugaritic literature describing the storm-god in his meteorological procession; yet Yahweh is not personified to the same extent.

\footnotetext{
${ }^{2}$ The Phoenicians had developed a phonetic alphabet in the $11^{\text {th }}$ century вс. The Phoenician-Old Hebrew script derives from it. By the $3^{\text {rd }}$ century, a script derived from the Aramaic script (known from the $9^{\text {th }}$ century) and called "the Jewish script" had replaced it (Cross 1961; Würthwein 1987, 3-11). Writing became the main mode of storing prophecy in Elijah, Elisha, and their disciples, although oral and written coexisted during the eighth and sixth centuries вС (Smith 2002, 191).
} 
In later texts, the absence of anthropomorphisms is even more salient, the emerging tradition of scribalism having put emphasis on other than mythical themes (Smith 2001, 175-178). We may, however, differentiate between anthropomorphisms in the literal sense and more abstract personalistic features that are normally attributed to personal agents (see Boyer 1996). To the first belong such features as, for example, God walking in the garden in the cool of the day and Adam hearing him (literally: "the sound of [him] walking;" Genesis 3:8-10). The narrative about God calling Moses from a bush that was on fire but did not burn up, and Moses hiding his face "because he was afraid to look at God" (Exodus 3:3-6), may be more difficult to classify in this sense. The first example derives from the so-called "Yahwist" source traditionally dated from the tenth to the sixth centuries вc. Maybe Yahweh was generally regarded in anthropomorphic terms at that time (Smith 2001, 88)? As to the second example, it has been hypothesized that El might have been the god connected with the exodus from Egypt (Smith 2001, 146-148); so, this narrative would be about El, not Yahweh.

The more abstract humanlike features also appear in the later strata in the traditions of the Old Testament. I am thinking here of such things as the fact that god is implicitly (or even explicitly) thought to see, hear, make promises, have emotions, and so forth (see Gnuse 2000, 4-6). In other words, he has similar cognitive capacities to humans; he is a personal agent. Being an agent and at the same time having some nonstandard properties, such as being without a physical body, is what unites the category of gods. As humans are prototypical agents, gods are often endowed with humanlike physical features (Boyer 1996; cf. Guthrie 1993). As the special powers of gods seem to be based on their non-human characteristics, an increase in power tends to go hand in hand with diminished anthropomorphism in representations of god (see Pyysiäinen 1997). So also the transcendence of Yahweh seems to have increased together with his elevation as the only true god; this, in turn, seems to relate to an increased awareness among the Israelites of themselves as a distinct nation (cf. Smith 2001, 175-178; Gnuse 2000, 13-25). Many generations of Christian theologians then have 
elaborated this representation of a powerful agent-God into a metaphysical principle quite alien to everyday religious thought.

\section{Theology and philosophy}

When Western Christians have adopted a reflective attitude to their faith, the result has been either skepticism or some kind of positive philosophical understanding of religious beliefs. Thus, when a believer wants to take rational argumentation seriously, (s)he will need to reinterpret his or her religious beliefs in some such way that both belief and rationality are maintained. Such combination of the mythical agent-God with the latest achievements of reflective thought of the time is found as early as in Hellenistic Judaism, particularly in Philo (c. 15 вс to 50 CE). Wolfson (1948, 3-9, 56-57) points out that the Alexandrian Jews, who learned Greek philosophy, were the only Hellenistic people who made a radically new contribution to it by remaking it according to the pattern of heir own belief tradition. In this, they developed what came to be known as the allegorical method of the interpretation of Scripture. Those unaffected by philosophy were satisfied with the traditional, literal interpretation; others, such as Philo, then tried to combine the traditional with a new kind of method, arguing that the literalists sometimes came to conclusions that contradicted their own beliefs. Thus, an allegorical interpretation was needed.

Philo (Legum allegoriae) assumed that the Scripture had a twofold meaning: a literal or obvious meaning and an underlying meaning only understood by the wise. For him, everything in the Scripture was subject to allegorical interpretation. One of his general rules was that all anthropomorphic descriptions of God, in particular, had to be understood allegorically. The essence of the Scriptural religion was that God existed and was one, and that also the Platonic ideas and the Mosaic Law existed. Only this last idea was exclusively Jewish (see Wolfson 1948, 115-116, 164-177).

Philo (De opificio mundi) also reinterpreted Plato's view of the creation of the world as presented in the Timaeus. He understood Plato to have argued that there was an unlimited void which, was the abode of the ideas, and that 
within it there was a limited void. This limited void was called a 'receptacle' and 'space' by Plato. In the limited void, there were copies or shapes of the ideal four elements. It was from these copies of the four ideal elements that Plato thought the world was created. The Demiurge ('the artisan') transformed these copies into the four elements, creating the world from these elements. Both the limited void and the copies of the four elements then came to be regarded as preexisting matter (see Wolfson 1948, 304-305).

Three problems remain here. First, Plato is inconsistent with regard to the origin of ideas and does not say whether the unlimited void was created. Second, he does not make it clear whether the limited void was created by God or had existed from eternity. Third, he does not make it clear whether the copies of the four ideal elements within the limited void were created by God or whether they had existed from eternity. Philo removed the first ambiguity by abolishing the unlimited void and by declaring that ideas were created by God. In like manner, he solved the second and third problems by saying that both the matter in which the world was created (the limited void) and the matter from which the world was created (copies of the four ideal elements) were themselves created by God. In Philo's opinion, the creation of the world of ideas is described in the Biblical account of the creation of the things created on the first day of creation (see Wolfson 1948, 305-306). As there could be no eternal beings besides God and as in God there could not be anything else than God, Philo thought that the Platonic ideas were integrated into an intelligible world of ideas (Plato's "intelligible animal") contained in a bodiless Nous ('mind') or Logos ('reason'). It had existed from eternity as God's thought; prior to the creation of the world, it was then created as a real incorporeal being (see Wolfson 1961, 32-38).

In this way, Philo gave a fine example of how to elaborate Old Testament mythological themes into metaphysical doctrines. The Apologists (c. 140-180) and later fathers of the Church then presented the Christian doctrine as a philosophy, restoring the original meaning of the few philosophical terms of the New Testament and providing a philosophical interpretation for many of the terms or concepts in the Scripture. This is how Christianity 
became philosophized: mythological themes and ideas presented in narratives and quite mundane everyday prose were elaborated into a grand philosophical system (see Wolfson 1961, 1, 39, 105).

In the "mystical" tradition of Christianity, beginning with Pseudo-Dionysius, neo-Platonic ideas were applied to argue that God was an uncaused cause of everything, beyond all perception and intellection (see Chadwick 1966, 14-15, 21, 68; Kenney 1991). Apart from mysticism, Philo's idea of the twofold meaning of the Scripture has been widely elaborated and applied in theology and philosophy more generally. Origen, for example, distinguished in the $3^{\text {rd }}$ century between simple and higher religious thinking, arguing that there was a difference in the mental capacity of persons even before the adoption of faith. The majority of believers could not follow rational argumentation and therefore leaned on a literal interpretation of the scripture, while the wise understood it allegorically (af Hällström 1984).

Origen's view was a precursor of the Islamic theory of two truths. At the turn of the $9^{\text {th }}$ and $10^{\text {th }}$ centuries, Al Farabi tried to combine Islam and Platonism-Aristotelianism, arguing that religion presented in symbolic form what philosophy presented more adequately on a more general level (Charlesworth 1972, 24-26). Averroës produced a more detailed version of this view in the $12^{\text {th }}$ century by distinguishing between philosophy (Aristotelianism), theology, and religion. All had the same object: an understanding of God and life; the difference was only in the method applied (philosophical reasoning, rhetoric, and dialectics) (Gauthier 1948, 21-40; Charlesworth 1972, 25-26) ${ }^{3}$.

The Platonic tradition dominated Christian theology until the $12^{\text {th }}$ century. The Aristotelian tradition then made its breakthrough in the $13^{\text {th }}$ cen-

\footnotetext{
${ }^{3}$ That this kind of interpretation does not have to be explained by historical contacts and influences alone receives support from the fact that Buddhist authors, too, have distinguished between two levels of truth in their tradition: the conventional or relative truth (samvrti satya) and the ultimate truth (paramartha satya) (see Nagao 1992, 13-22). The relative truth corresponds, correctly or incorrectly, to the appearances of things, while the ultimate truth is not an object of cognition and cannot be conveyed in syllables. The idea of two truths could thus well reflect some general propensity of human cognition (see Pyysiäinen 1996) responsible for the obsession of somehow getting behind appearances (Pyysiäinen 2004b, 187-204).
} 
tury, after the Arabic translations of Aristotle's writings had been translated into Latin, accompanied by the commentaries by Avicenna and Averroës. Aquinas (c. 1225-1274) already had the whole Aristotelian corpus available, although translations from the original Greek became common only in the $15^{\text {th }}$ century. In his Summa theologiae (I Q III art. 1-8), Aquinas applied Aristotelian ideas in trying to explain how God should be understood (see also Wolfson 1959; 1961, 59-63). He argued, for example, that:

1. God does not have a body (Deum non esse corpus).

2. God is not a composition of matter (materiam) and form (forma).

3. God is one with his essence (essentia) and nature (natura).

4. God is not only his essence but also his existence.

5. God is not in any genus as a species (Deus non est in genere sicut species) or as a cause (sicut principium).

6. There can be no "accidents" (accidens) in God

7. God is totally one (Deum omnino esse simplicem).

8. God cannot be combined with anything.

This can still be considered as representative of the way the Catholic Church teaches about God. Yet, beginning from the $14^{\text {th }}$ century at the latest, the Aristotelian ideal of merely describing the already known order of things and thus rearranging extant knowledge was gradually replaced by the novel ideal of empirical science that aimed at discovering new things. This development was made possible partly by the new kind of modal logic called "Nominalism" (Knuuttila 1993a). To the extent that everything now seemed to happen because of contingent, natural reasons, not because of a pre-established divine harmony, the concept of 'God' seemed to have become useless in the Enlightenment picture of the world. The world could still be conceived of as a divine creation, but 'God' was not needed to explain how the world functioned (see Pyysiäinen 2004b, 190-192).

Notwithstanding the appeal the "literal interpretation" of the Bible still has in many circles in our millennium, new versions of the allegorical 
method also continue to be popular and acquire ever new forms (cf. Malley 2004). In biblical studies, a liberal attitude was best exemplified in the Religionsgeschichtliche Schule that prospered from 1897 until World War I which then put an end to the dominion of liberal theology and any wider interest in the history of religions within biblical studies (Räisänen 2000, 21-41). New trends soon emerged, however, and the liberalization of theology had come to stay. As it is not possible to analyze these trends in any detail within the present confines, I shall only briefly describe one theologian's, Paul Tillich's, view of God.

When Tillich $(1967$, I, 163, 235) says God was "the answer to the question implied in being", or that the being of God is "being-itself", this must sound somewhat mysterious for anyone not familiar with Heidegger and existentialist philosophy. The statement is a characterization in which 'God' serves as a more or less empty placeholder that the author then fills up with his favorite kind of philosophy (see Gnuse 2000, 1). Tillich (1967, I, 211) goes on to explain: "'God' is the answer to the question implied in man's finitude; he is the name for that which concerns man ultimately.... It means that whatever concerns a man ultimately becomes god for him, and, conversely, it means that a man can be concerned ultimately only about that which is god for him".

In the background figures Tillich's (1967, I, 18-28, 230) distinction between philosophical and religious attitudes. While philosophy deals theoretically with the structure of being, religion deals existentially with the meaning of being. Yet religion can only express itself through the ontological elements and categories of philosophy, and philosophy can discover the structure of being only on the condition that being-itself has become manifest in an existential experience expressed in the idea of God. Theology, for its part, can deal with assertions about the nature of being either philosophically, evaluating their truth, or existentially, struggling with them as expressions of ultimate concern on religious grounds.

Tillich (1967, I, 223) claims that man is "radically concerned only about that which can encounter him on equal terms", that is, on a person to per- 
son level. This is constitutive of religious experience. In every religion a struggle for a personal God resists all philosophical criticism. Thus, stones and stars, as well as plants and animals, and also angels and spirits are endowed with personal characteristics, when they appear as symbols of human ultimate concern.

This means also a struggle between polytheism and monotheism. There are three types of monotheism: monarchic, mystical, and exclusive. In the first, God represents the power and value of the hierarchy of polytheistic gods. Mystical monotheism is an attempt to suppress the quest for concreteness in representations of God (i.e. personal features) but does not completely succeed in it. Only exclusive monotheism is able to resist polytheism; in it an abstract transcendence develops, as the concrete god is elevated to ultimacy and universality. God is not a being, not even the highest being, but rather being-itself. Yet this development is supposed to take place without the loss of the concreteness of a personal God. (Tillich 1967, I, 225-229, 235-237.)

This, however, seems to contradict what Tillich says about encountering God as a person. He therefore hastens to admit that the God of exclusive monotheism "is in danger of losing the concrete element;" the ultimacy and universality of God tend to swallow his concrete character as a living God. When personal features and anthropomorphisms are removed, God seems to be reduced to the philosophical absolute. (Tillich 1967, I, 227-228; see also Ferré 1984.) Tillich (1967, I, 229) then explains that God's transcendence is not the infinite abyss of mysticism; it is rather the transcendence of "the absolute command which empties all concrete manifestations of the divine". But, as the concrete element cannot be simply rejected, certain mediating powers must be assumed. These are the historical person of Jesus Christ, angels, and hypostasized divine qualities such as Wisdom, Word, and Glory.

In the $13^{\text {th }}$ century, Aquinas and Albert the Great had referred to the divine qualities as God's "attributes" (attributio); as Ockham (Quodlibet III.2) observes in the beginning of the 14th century that "the ancient Saints did not use the word 'attributes', but instead used the name 'names'", this 
must be a new development. Attributio had most probably been adopted as a substitute for the more conventional nominatio from Maimonides' Guide of the perplexed written in Arabic. The Latin translation of its Hebrew translation was published in 1235 at the latest. In that book, Maimonides described the Islamic debate on the attributes of God, with the Arabic word sifah then being translated in Latin as attribution. In the debate, the $\mathrm{Mu}^{\prime}$ tazilites had in the $9^{\text {th }}$ and $11^{\text {th }}$ centuries argued that the attributes of God were identical with God, not separate beings in him, thus denying all anthropomorphic descriptions of God. Also Aquinas now thought that the attributes were actually only one idea that was identical with God himself (Wolfson 1959; 1961, 49-52).

Tillich (1967, I, 229-230, 239-240) argues that it is in the mediating powers that the absolutely transcendent God becomes concrete and present in time and space. As the distance between humans and God increases, the significance of these mediating powers grows, ultimately resulting in the paradox of the simultaneous humanity and divinity of Jesus. Yet all concrete assertions about God "must be symbolic". In a symbolic description of God, a segment of finite experience is both affirmed and negated at the same time. As also Aquinas had argued, the via negativa does not mean that God lacks some attributes but that he exceeds them.

It is difficult not to agree with Nielsen when he writes that with Tillich's talk about Being-itself, just as with Thomistic jargon, "it becomes utterly unclear what, if anything intelligible, is being affirmed that a skeptic could not affirm as well". Protestant thinkers, such as Tillich, claim that they "believe in something mysterious and profound and crucial to the human condition" of which the nonbeliever has no real understanding. Yet they seem incapable of articulating what this something is. (Nielsen 1985, 37.)

To the extent that theologians are neither willing to deny the validity of scientific inquiry nor to substitute scientific explanations for religious ones, they are left with the option of claiming that religion serves some autonomous function and that scientific progress is irrelevant from the religious point of view (cf. Ruse 2003, 330-336). As it is possible to argue, for example, 
that "Jesus Christ is our redeemer' is true", without any specification of the meaning of 'Jesus Christ is our redeemer' (see Sperber 1995; 1996, 56-150), the theologian makes the best of this opportunity. The task is simply to provide statements that seem to somehow fit with the target claim. As Nielsen $(1985,25)$ again observes, Protestant thinkers are well aware of the problematic nature of religious concepts and beliefs, and yet they seek to make sense of these beliefs, trying to "bring to the fore their vital human import in the teeth of their paradoxical nature and their apparent incoherence". In the Conclusion, we shall return to the question of why this is so.

\section{God of the philosophers}

The concept of God also continues to be one of the great philosophical problems. It can be approached either as a technical problem (e.g., Kenny 1979), or as a specifically religious problem, although the difference between these two is by no means clear (see Dalferth 1981). In the first case, 'God' is often regarded as a more mythical-allegorical concept the true meaning of which is better understood through philosophical analysis, as Leibniz, Spinoza, Hegel, and many others have argued (see Charlesworth 1972, 27-32); Schopenhauer (1947, 344), for example, describes religion as allegorical "folk-metaphysics".

The latter option of approaching 'God' as a specifically religious concept is represented by much of the philosophy of religion that emerged after the Enlightenment; it has often had the aim of making religious belief comprehensible in the age of science, much as in philosophical theology ${ }^{4}$. In other words, it is not studied whether belief is rational but rather in what sense it is rational.

In the Anglo-Saxon discussions, a central strategy has been to argue that religious beliefs are not hypotheses about empirical phenomena. How exactly their cognitive status should be understood has been a matter of debate (see Flew and MacIntyre 1972; Hare 1963; Ferré 1967; Phillips 1976;

\footnotetext{
${ }^{4}$ In addition, there are also some attempts at showing atheism to be a more rational stand compared to religious belief (Martin 1990; Nielsen 1985; 1989).
} 
1988; 2000; Alston 1991; 1994). After Ayer (1936) had argued that it was impossible to verify religious claims, a number of reactionary responses were developed. Wisdom (1944) agreed that the existence of God was no longer an experimental issue in the way it used to be, because people now had better knowledge of why things happen as they do. Whereas questions such as "Do dogs think?" are partly metaphysical (conceptual) and partly scientific (empirical), questions about God have gradually become wholly metaphysical. This Wisdom illustrates by the following story (Wisdom 1944, 188, 191-193):

Two people return to their long neglected garden. One then opines that a gardener obviously has been doing something about the plants. It turns out, however, that no neighbor has seen anyone at work in the garden. The other person begins to think that there is no gardener, but the first one points out that there is such an order and such beauty in the garden that a gardener must be taking care of it. The second person replies that a gardener would have kept down the weeds in the garden, trying to argue that it is extremely unlikely that the gardener really could have worked without being noticed. The first person still insists that an invisible and elusive gardener tends the place, while the other one is ever more skeptical. After all rational arguments and empirical evidence has been considered, the persons are still left with the simple fact that one believes in the gardener and the other one does not.

At this stage, the gardener hypothesis has ceased to be experimental, says Wisdom. In the simile, one person is not expecting something the other does not expect. Consequently, it seems that we cannot say which one is right and which one wrong in his or her belief. And yet the difference is not merely in the exclamations with which each party faces life. The disputants speak as if they are concerned with trans-sensual and trans-scientific facts. The point, however, is that the dispute involves feelings and thus is more like a dispute over the alleged beauty of an object (Wisdom 1944, 192, 196).

Antony Flew (1972) argued in 1955 that if this is the case, then religious beliefs are nonsensical; they cannot be falsified by any evidence and thus are compatible with all possible empirical states of affairs. Therefore, they 
cannot have any meaning. Among the many replies Flew got, was Hare's (1963) argument that there can be different kinds of unfalsifiable claims or beliefs, and that it is not irrelevant to which ones one holds to. The claim that everything happens by pure chance, for example, is compatible with every possible kind of evidence; yet when adopted, it clearly has some important consequences for people's lives - and rather disastrous ones. Thus, also Christian beliefs are consequential, even if they are unfalsifiable. Later the idea that all empirical claims are quite irrelevant from the religious point of view has been elaborated in what has come to be known as "Wittgensteinian" philosophy of religion (e.g., Munz 1959; Phillips 1976; 1988; 2000; Pihlström 2002; see Martin 1990, 256-261; 1991; cf. Wittgenstein 1966).

More recently, philosophers such as Alvin Plantinga, William Alston, and others, following Calvin, have argued that philosophers of religion should not try to convince skeptics but rather explicate the inherent rationality of Christian beliefs that emerges once one accepts such "basic beliefs" as, for example, that God exists. Plantinga (1990), for instance, regards the belief that God exists as a similar kind of foundational conviction as the one that other minds exist; it is based neither on empirical evidence nor on deductive reasoning (cf. Barrett 2004, 97-105). Arguments for the existence of God are thus not needed for rational belief (see Martin 1990, 266-277).

However, this view leads to absurdities as soon as one generalizes the basic principle. Practitioners of voodoo, or Satanists, could equally claim that their belief systems are rationally justified once one accepts the "basic beliefs" of their system (Martin 1990, 272-276). Much of continental philosophy of religion, for its part, differs both from the Anglo-Saxon analytic tradition and the reformed epistemology. Dalferth (1981), for instance, interestingly argues that belief in God cannot be analyzed separately from Christian practice ${ }^{5}$.

As far as the more technical discussions of religious concepts and beliefs are concerned, they are well exemplified by the traditional ontological, teleological, and cosmological arguments for the existence of God (see

\footnotetext{
${ }^{5}$ On philosophy of religion generally, see Stump \& Murray 1999; Yandell 1999; Taliaferro \& Griffiths 2003.
} 
Martin 1990, 79-153). Of these, the ontological argument is a purely a priori argument. Anselm of Canterbury (Proslogion 2, see Plantinga 1968, 3-30) originally presented this argument as follows: the fool thinks that God is (by definition) a being such that no greater being can be conceived; in addition, he thinks that God does not exist. But this involves a contradiction, as the fool believes himself to be thinking of the greatest possible being, and yet a great being that exists is greater than the one the fool is thinking of (which does not have the property of existence). Thus, denying that the greatest possible being exists, involves a contradiction; it is therefore necessary (to think that) that God exists.

There are various modern versions of this argument (Plantinga 1968, 123-172; Martin 1990, 85-95) all of which ultimately boil down to the claim that God must exist because he is defined to exist (Edis 2002, 23-27). It has been shown that this kind of argument cannot establish God's existence as a fact (Martin 1990, 80-95). It is, for example, possible to evoke the same argument to prove the existence of an absolutely evil being; as God and an absolutely evil being (i.e. one not subordinate to God) cannot both exist without contradiction, there must be something wrong with the argument. The crux of the matter is that the "fool" need not include nonexistence within the concept of God; they merely think that, although existence is one of the properties of a being such that no greater being can be conceived, this concept has no reference in the real world (Martin 1990, 81-95). An empirical scientist, compared to a philosopher, is even more astonished at the attempts to bring entities into existence by mere definitions (Edis 2002). Yet the ontological proof continues to attract some philosophers of religion who seem to hope that some day a valid version of it can be developed.

The cosmological argument, known to Plato and Aristotle as well as Aquinas and later philosophers, says that as everything must have a cause and as there can be no infinite regress of causes, there must be a first cause. This, then, is supposed to be God (e.g., Aquinas's Summa Theologix I, Q II art. 3; see Martin 1990, 96-124). Aquinas is here not thinking about a first cause in a historical sense; he rather means that there must be a logically 
first cause that maintains the universe here and now. In the light of modern science, the ideas of the impossibility of an infinite regress of causes and of the necessity of a first cause are, however, unnecessary postulates (Edis 2002). Even more problematic is the claim that such a first cause should be be identified with the Christian God (Martin 1990, 100).

A modern version of the argument has become known as the "Kalâm cosmology", according to William Craig's argument that borrows from the Arabic Kalâm movement (Craig 1979; Craig \& Smith 1995). Ilm al-Kalâm ('word, discourse, inference') is an Islamic branch of knowledge focusing on the being and attributes of God as well as creation, trying to provide discursive arguments in support of religious belief. The Kalâmists (mutakallimûn) may be related to the Mu'tazilites mentioned above (see Wolfson 1961, 49-52).

Craig (1979, 20-34, 149-153) argues that the beginning of the universe must have a cause, because an actual infinity of events is impossible. The cause of the universe also must be a personal being. This is because, if the necessary and sufficient conditions for the production of the first event are present from eternity, then also the effect (the universe) will exist from eternity; if they are not, then the first event could never occur (because the necessary and sufficient conditions could never arise). Yet the universe began to exist when it did, instead of existing from eternity. Why this happened is explained by the Islamic principle of determination: "When two different states of affairs are equally possible and one results, this realization of one rather than the other must be the result of the action of a personal agent who freely chooses one rather than the other" (Craig 1979, 150-151). While no mechanical cause existing from eternity could have created the universe, such a production of temporal effect from an eternal cause is possible if and only if the cause is a personal agent. Only a personal being can freely choose to create at any time.

Martin $(1990,103)$ complains that this aspect of Craig's argument "is very condensed and obscure". The point, however, can relatively safely be said to lie in the difference between mechanical causality and agent causality: an eternal mechanical cause cannot produce an effect at a point in time 
because then we would need a secondary cause to explain why the first cause produced the effect at this particular point in time. An agent, however, could exist from eternity and then, suddenly, create the universe at some point in time by a decision of free will.

Unfortunately Craig's argument fails for other reasons. The whole argument rests on two premises: that actual infinity is impossible (Craig \& Smith 1995, 9-24, 83-85, 92-99), and that beginnings must have causes. Craig opines that the premise, according to which everything that begins to exist has a cause, "is so intuitively obvious, especially when applied to the universe, that probably no one in his right mind really believes it to be false" (Craig \& Smith 1995, 57). However, what is possible and what is impossible in the physical reality does not at all depend on what humans can or cannot believe. This should be obvious. As the physicist Taner Edis (2002, 95-97) puts it, physics does not respect people's intuitions; the principle that beginnings require a cause is just plain wrong. "(U)ncaused events are the rule in our universe." Likewise, there is nothing formally wrong with the idea of actual infinities, even if Craig is unable to imagine them. Humans have no natural preparedness to process cognitively the idea of infinity; we therefore employ spatial metaphors that, however, can often be mathematically misleading (Lakoff \& Núñez 2000).

Even if Craig's argument were sound, it would not prove that the creator of the universe is omnipotent, omniscient, and so forth. As Craig himself (1979, 172-173 n. 171) says, such things can only be known through revelation. Therefore, it is difficult to see why the argument would prove the existence of God and especially the one and only God of the Judeo-Christian-Islamic traditions.

The teleological argument, for its part, is usually interpreted as an argument from design: as the universe seems to be complex, it must be intelligently designed. The classical formulation of this argument is from William Paley's book Natural Theology from 1802 (see Martin 1990, 125-153); as the argument has recently been revived with great fanfare within the empirical sciences, I will deal with it separately in the next section. 


\section{"Intelligent design"}

The idea of nature as a "book" in which we can recognize the handwriting of God is age-old. St. Augustine, for example, thought that God authored both the Scripture (liber scripturae) and the "book of nature" (liber naturae) and that the Scripture contained all possible truths (Confessiones XII.42); in the $14^{\text {th }}$ century the divine intellect came to be regarded as a book containing everything that could be known (Knuuttila 1993b, 355). In the $16^{\text {th }}$ century, Richard Hooker argued that Nature and Scripture were the two sources we should study to get to know the Creator (see Ruse 2003, 36). Paley, for his part, considered revelation and the argument from design to be two distinct alternatives. The argument from design proved the existence of God beyond doubt; besides, it could also enrich the faith of the believer. The natural world simply manifested such a design that one could not but reason the presence of a designer (see Ruse 2003, 41-45). Later, Frederick Tennant (1968, II, 121) argued that, although the particular instances of apparent design might be explained by naturalistic theories, the "multitude of interwoven adaptations" had to be explained with reference to purposive intelligence (see Martin 1990, 128-135).

Modern versions of this argument took start in 1961 when Whitcomb and Morris's book The genesis flood was published. Their view came to be known as "creation science" or "scientific creationism". In a number of publications to follow, the earth was explained as a creation of God and to be roughly 6,000 years old, according to biblical calculations (see Evans 2000, 306-310). In the 1990's a new group of evangelical Christians started a neocreationist movement under the intellectual banner of "intelligent design" (ID) (see Ruse 2003, 315-328; Young \& Edis 2004). Although the details of the biological arguments involved are alien to most scholars of religion, it is necessary to deal with them in order to show that it is not biological facts as such that force the scholar to reason from apparent design to intelligent designer. We need to look for something else. As the ID arguments are based on criticizing evolutionary theory rather than on positive arguments, I shall proceed by criticizing the criticism. In this way it is possible to show how the argument from design actually comes into play. 
In 1993, the Berkeley law professor Phillip Johnson published his book Darwin on trial in which the accused was, to quote Ruse $(2003,315)$, "tried, convicted, and led away in chains". However, soon the strategy was shifted to outlining a more positive alternative for evolution, with as little explicit theology as possible; the main goal was to show that the world had an intelligent designer, much as the "Kalâm cosmology" had postulated. Yet it was no secret that this designer was ultimately thought to be the Christian God; such occasional slips of the tongue as "As Christians we know" confirm this (Ruse 2003, 316; Perakh \& Young 2004). Behe (1996, 232-233), for instance, proclaims: "The result of these cumulative efforts to investigate the cell ... is a loud, clear, piercing cry of 'design!' The result is so unambiguous and so significant that it must be ranked as one of the greatest achievements in the history of science." Yet: "no bottles have been uncorked, no hands slapped. Instead, a curious, embarrassed silence surrounds the stark complexity of the cell". Why is this so? Behe's (p. 233) answer is that "while one side of the elephant is labeled intelligent design, the other side might be labeled God". There are various reasons for the reluctance of studying the God-part of the "elephant" but the most powerful one is that scientists "just don't want there to be anything beyond nature" (p. 243).

What is new in this movement, are the detailed scientific arguments presented to support the claims of intelligent design. As Ussery $(2004,56)$ puts it, "I have talked with people who advocate intelligent design, and they simply cannot understand why their manuscripts, which contain such weak and minuscule evidence, are not published in scientific journals". It should not go unnoticed, however, that some of these scholars, such as Michael Behe, have done and continue to do perfectly ordinary and good scientific work - that is, when they are not advocating ID.

Behe's (1996, 39-42, 70-73) basic claim is that biological organisms manifest "irreducible complexity" which cannot have evolved because natural selection can only choose systems that are already working. Such complex units as, for example, the bacterial flagellum cannot have evolved gradually; such a biological system "would have to arise as an integrated unit" (p. 39). Behe $(1996,42-45)$ first uses the common mousetrap as an analogy: it is ir- 
reducibly complex in the sense that it consists of at least five parts without which it cannot function. (This, however, is completely wrong: the trap can be reduced until only the spring remains, and it still works [see Young 2004, 21-22].) Behe's biological example, then, is the flagellum, a long, hair-like filament embedded in the cell membrane, which is a simplified version of the cilium and consists of about 40 proteins. Behe $(1996,69-73)$ cannot imagine how the three parts of the flagellum - the paddle, rotor, and motor - could have evolved together, because half a flagellum is no good, just as the creationists have (incorrectly) claimed about half an eye (see Young 2004, 20-25; Ussery 2004, 49-51).

The irreducibly complex structure of the flagellum is made of proteins. The E. coli strain K-12 has 44 flagellar proteins, whereas Cambylobacter jejuni has only 27 , for example. Behe is unclear as to what is the minimum amount of proteins needed for an irreducibly complex structure, thus leaving it open where exactly lies the supposed boundary between irreducible complexity and reducible complexity. The paddle, for instance, consists of a set of proteins called flagellin; if one takes individual copies of the protein and mix them together, they will spontaneously polymerize to form the paddle. Furthermore, each of the three parts of the flagellum may have had other functions in the cell before coming together to form the flagellum. There seems to be only a loose coupling between the proton-driven motor and rotation of the flagellum, for example (Ussery 2004, 50-53; Musgrave 2004).

Moreover, proteins do not evolve. Natural selection operates on organisms and genes, with evolution taking place as changes in DNA sequences, which also happens in bacteria. Behe (1996, 227-228) argues that the intelligent designer might have put all the necessary genes into the first organism "long, long time ago". Here Behe completely ignores the problem of the immense period of time separating this supposed event from the point in time that the genes are finally expressed in given phenotypes. Every biologist knows that when genes are not expressed, natural selection cannot discard genetic mistakes and mutations will render these genes inoperative hundreds of millions of years before the time at which they will be needed in Behe's scheme. (Ussery 2004, 52-54; Ruse 2003, 321-322.) 
So, not only is there nothing wrong with the idea of evolution: the proposed alternative is also a nonstarter. Behe and his colleagues have been hopelessly incapable of providing any sensible explanation of how, and by whom, the intelligent designing has supposedly been carried out, as shown in detail by Korthof (2004) and Edis (2002; 2004b, 144, 152). Dembski (2002), however, backs Behe by arguing that pure chance could not have produced such complex and specified structures as found in living organisms. What he overlooks, however, is the combination of chance and necessity. Selective forces operating on randomness can create specified complexity, as many authors have shown (Ruse 2003, 322-328; Edis 2002; 2004b; Hurd 2004; Perakh 2004; Shallit \& Elsberry 2004).

I have emphasized in some detail the fact that the arguments about ID do not have any scientific basis, in order to make it clear that their popularity must be explained by other, that is, religious factors. Its supporters have so far managed to publish only one peer-reviewed paper in a scientific journal; this happened when the former editor of the low-impact journal Proceedings of the Biological Society of Washington, Richard Sternberg, himself a supporter of intelligent design, accepted in 2004 for publication Stephen Meyer's (2004) paper arguing that the complexity of living organisms cannot be explained by Darwinian evolution (Giles 2004; Stokes 2004).

Although intelligent design is an extreme view, its basic tenet is implicitly shared by many theologians, albeit in a more metaphorical form. The theologian-physicist John Polkinghorne (1998), for example, speculates on how an intelligent guidance of evolution might be possible, given the indeterminism in modern physics. Yet he never develops a clear argument for information and quantum randomness as a space for divine action (Edis 2004a, 14). The Old Testament scholar Robert Gnuse (2000), for his part, has tried to combine the God of the Old Testament and an Alfred Whitehead -type of process philosophy. Thus, while people like Polkinghorne are more interested in theology than in science, the advocates of intelligent design are more interested in science than in theology. Neither is capable of bridging the gap between religion and science. 


\section{God explained}

\section{Intuitive and reflective thinking}

The Old Testament narratives describing the deeds of Yahweh partly reflect people's spontaneous, intuitive way of thinking about gods and other counterintuitive agents (see below). Theology, philosophy, and science represent reflective thinking. I shall explain this difference with reference to the socalled dual-process theories (Pyysiäinen 2003b; 2004a). It has been argued in social psychology, neuropsychology and cognitive science that humans have two different types of cognitive processing systems. The processes, however, do not work independently of the kinds of external mnemonics that are available in culture (writing, social institutions, etc.) (see Pyysiäinen 2004a; Evans 2003). My point here is that the two types of cognitive processes seem to support two very different kinds of god concepts (see Barrett \& Keil 1996; Barrett 2004).

Of these two systems, one is spontaneous, automatic, and intuitive, the other one being reflective, consciously controlled, and systematic. The two systems serve different functions, are applied to differing problem domains, have different rules of operation, correlate with different kinds of experiences, and are carried out by different brain systems. Briefly put, the automatic system produces fast intuitions of how things are, without our necessarily being consciously aware of this; it thus makes adaptive behavior possible. The system can be modeled by so-called "neural nets" with parallel distributed processing of information. The intuitive system operates reflexively and draws inferences and makes predictions on the basis of temporal relations and similarity. It employs knowledge derived from personal experience, concrete and generic concepts, images, stereotypes, feature sets, and associative relations. It uses similarity-based generalization, and automatic processing; it serves such cognitive functions as intuition, fantasy, creativity, imagination, visual recognition, and associative memory (Pyysiäinen 2003b; 2004a; Sloman 1996; Lieberman et al. 2002; Evans 2003).

The reflective system is a rule-based system that is able to encode any information that has a well-specified formal structure. Such a structure 
also allows the generation of new propositions on the basis of systematic inferences, as well as genuine explanations, in contrast to mere predictions. These inferences are carried out in a "language of thought" (Fodor 1975) that has a combinatorial syntax and semantics. It thus explicitly follows rules, seeks for logical, hierarchical, and causal-mechanical structure in its environment, and operates on symbol manipulation. It derives knowledge from language, culture, and formal systems; it employs concrete, generic, and abstract concepts, abstracted features, compositional symbols and causal, logical and hierarchical relations. It serves such cognitive functions as deliberation, explanation, formal analysis, verification, ascription of purpose, and strategic memory (Pyysiäinen 2003b; 2004a; Sloman 1996; Lieberman et al. 2002; Evans 2003).

The automatic or intuitive system supports god concepts that people use spontaneously, without much reflection, making inferences and predictions on the basis of temporal relations and similarity; the reflective system processes such highly elaborated god concepts as those found in theology and philosophy, trying to improve the performance of the automatic system by generating new propositions on the basis of systematic inferences and explanations (Pyysiäinen 2004a, 134-136). Barrett (1999) calls people's reflective beliefs about their own beliefs "theologically correct" because they represent what is commonly regarded among believers as the "right" things to believe. Barrett's empirical studies, however, show that in fast "on-line" reasoning people make inferences from a much simpler and more concrete representation of god (Barrett \& Keil 1996; Barrett 1998). Thus there is a difference in what people believe and what they believe they believe. The difference is based on the difference between the two kinds of cognitive processing (see also Bless \& Fiedler \& Strack 2004, 26-29, 38-39, 60-66).

Wisdom's (1944) claims notwithstanding, there is no unilinear historical development from a quasi-experimental religious attitude towards a more metaphysical understanding of religious belief. It is rather that people apply both of the different reasoning systems to varying extents. In living religiosity, both systems are involved but their relative contributions differ. Spontaneous religious reasoning relies more heavily on the intuitive system, 
while theology relies more on rational processing and the related cultural institutions. In the intuitive system, God is usually not experienced as a problematic concept (Barrett 2004); it is only after the rational system begins to contribute that the inherent problems of the concept become apparent.

\section{Counterintuitive agent-representation}

Yahweh belongs to the category of "counterintuitive agents" as described by Pascal Boyer (1994; 1996; 2000; 2001), Justin Barrett (2004), E. Thomas Lawson (2001), Scott Atran (2002, 95-100), and myself (Pyysiäinen 2001, 9-22; 2004, 39-52). By an agent is generally meant an organism that seems to act on the basis of its beliefs and desires. It is a special feature of human psychology that we are capable of an elaborate understanding of the states of mind of conspecifics and thus of predicting their behavior creatively, not merely by a mechanical stimulus-response model.

There are different views, sometimes called "theories of theories of mind", of what kinds of mental mechanisms are involved in our ability to understand, explain, and predict our own actions and the actions of other agents. The so-called "theory-theorists" take this ability to be based on a folk-psychological theory of the structure and functioning of the mind. This folk-theory may be innate and modular in nature, learned individually, or internalized in enculturation and socialization. An alternative view is the simulation theory, according to which we understand other minds by simulating alien mental states in our own mind. This is based either on the primacy of introspection, or on identification with the other, without introspective self-awareness. In addition, there are also mixed views (see Carruthers \& Smith 1996; Gallagher \& Frith 2003). Autistic symptoms, for instance, seem to be based on a deficit in this ability of "mind-reading" (Carruthers \& Smith 1996, 223-273; Baron-Cohen 2000; Frith 2001; Avikainen 2003, 13-20, 60-64).

Yet it has become clear that there is no unified "theory of mind" system with a single evolutionary background (Boyer and Barrett, in press). Some have argued that humans are "hard-wired" to categorize automatically ap- 
parently self-propelled entities as agents (Premack 1990; Leslie 1994; 1996; Leslie \& Friedman \& German 2004). This seems to be supported by Heider and Simmel's (1944) early work, showing that, under certain circumstances, we tend to attribute agentive properties even to mere objects and geometric shapes, guided by only minimal cues. Agent detection is hyperactive in the sense that even such minimal cues can trigger the postulation of agency (Barrett 2000, 31-32). We use agent-explanations whenever possible (see Pyysiäinen 2004b, 1-27).

Blakemoore et al. (2003) distinguish between mechanical and intentional contingency, emphasizing that the detection of intentional contingency, or agency, is based either on type of motion or on interaction between objects: movement that is self-propelled and shows unpredictable changes in velocity is perceived as animate, even if it is not enacted by human bodies. So is movement based on reaction at a distance. Mechanical and intentional contingency are also processed in different parts of the brain, detection of mechanical contingency being low-level processes not influenced by higher order processes. The detection of agency might thus be a precursor of the ability to infer other people's mental states (Blakemoore et al. 2003, 837; see also Gergely \& Csibra 2003; Csibra 2003).

There is also empirical evidence to support the conclusion that agency attribution may not be based on seemingly self-propelled movement as the cue, and that it does not necessarily presuppose an understanding of psychological states. Atran (2002, 64-67) argues, on the basis of Csibra et al. (1999), that children attribute goal-directedness to certain kinds of "telic" event structures, rather than to entities. What is important here is contingent control over the outcome of the telic situation, not the initiation of action. The importance of control over movement is also supported by the empirical study of Barrett and Johnson (2003).

Infants as young as nine months of age are able to represent the observed behavior of objects in teleological terms; yet they do not necessarily do it in mentalistic terms and are not necessarily committed to any specific ontological categorization of these objects (Csibra et al. 1999). There are (at 
least) two distinct ways of doing this. First, nine-month-olds are capable of taking the "teleological stance" and representing actions as being directed towards a goal. Actions are not connected to their antecedent causes but to their consequences, but without attributing mental states to the acting entities. Second, actions such as pointing and looking at an object can be interpreted as being referential in the sense that action is linked to a specific object or an aspect of the environment. The action is about something. (Gergely \& Csibra 2003; Csibra 2003.)

Thus, following Boyer and Barrett (in press), it is advisable to break the "theory of mind" into such separate cognitive operations as animate motion detection, distant reactivity, goal-ascription, intention-ascription, joint attention, and facial cues about emotional states. The detection of animate motion has as its input such things as non-linear changes in direction, sudden acceleration without collision, and change of physical shape accompanying motion (e.g., caterpillar-like crawling). Animacy can also be attributed on the basis of an object reacting at a distance, rather than on the basis of presupposed self-propelledness. Goal-ascription is a related capacity based on the presupposition that certain trajectories make sense only on the condition that the moving entity is trying to reach or avoid something. A more complicated process is intention-ascription in which the end-result of an action is connected to perceived movement through the link of the intention of the moving organism. Joint attention develops in humans between nine and twelve months, proceeding from joint engagement to communicative gestures and attention-following (like gaze-following). Lastly, facial expressions are used as cues about emotions as early as in five-month-olds who react differently to displays of different emotions on a familiar face.

In terms of the underlying neural processes, one option is that the prefrontal cortex inhibits the natural tendency to act on mere correlative stimulus relationships, guiding us to search for higher-order associations and recursive embeddings as well as directly helping us process difficult syntactic constructs (see also Fuster 2002). Prefrontal activity thus outperforms other brain processes and we come to rely on its functions whenever 
possible (Deacon 1998, 265-267). Thus we are able to process such complicated intentional structures as "Marilyn knows that Helen wants Tom to think that Allison wishes...", and so forth. This involves the so-called recursion principle, that is, the principle of rules within rules. This feature defines language in particular but it is also involved in many kinds of human thought and action; pupil A can, for example, watch pupil B watch pupil $\mathrm{C}$ watch the teacher. Apes, being incapable of using recursion, only each other directly (see Fitch \& Hauser 2004; Premack \& Premack 2003, 150-153; cf. Tomasello \& Call \& Hare 2003).

Another recent suggestion is that "mind-reading" might be based on the so-called mirror neuron system (Gallese \& Keysers \& Rizzolatti 2004; Pyysiäinen forthcoming). Mirror neurons were first found in monkey brains in premotor area F5 and parietal area $7 \mathrm{~b}$. These neurons were activated both during the execution of purposeful, goal-related hand actions (grasping, etc.) and during the observation of similar actions performed by conspecifics (see Rizzolatti et al. 1988; Gallese et al. 1996; Gallese \& Goldman 1998; Rizzolatti et al. 2000). Such sensorimotor integration instantiates an "internal copy" of actions by which goal-related behaviors are generated and controlled. At the preconceptual level it also provides a meaningful account of behaviors performed by others (Gallese \& Metzinger 2003; see Bremmer et al. 2002).

A similar mirror system has also been found in humans. When a given action is planned, its expected motory consequences are also forecast, and during action observation there is strong activation of both premotor and parietal areas (with inhibition of action taking place in the spinal cord [Rizzolatti \& Arbib 1998] much as in dreaming): there is an equivalence of what is being acted and what is perceived. Both are implicit, automatic and unconscious simulation processes that establish a link between an observed agent and the observing agent (Hari et al. 1998; Gallese \& Metzinger 2003).

The mirror neuron system seems to play an important role in social communication; its dysfunctions can cause autism-like deficiencies, for example (Avikainen 2003). It serves as the basis of the human ability to directly understand the meaning of the actions and emotions of others through an internal 
replication, without conceptual reasoning. Simulation of action is based on a neural system responding both when one executes a particular goal-directed action and when one observes someone else performing a similar action. This system is located in the inferior parietal lobe, inferior frontal gyrus and the adjacent part of the premotor cortex. Simulation of emotions is processed in the anterior insula and the amygdala, which are activated during both observation and imitation of facial expressions of basic emotions (see also Pyysiäinen 2001, 97-109). The activation of the neural structures involved in own personal experience thus also forms the bridge between ourselves and others. Social cognition is not only thinking about the contents of other minds but also very much a question of sharing an experience (Gallese \& Keysers \& Rizzolatti 2004; Gallese \& Metzinger 2003).

It is such cognitive operations and neural processes that also underlie the human capacity to postulate counterintuitive agents. Although agency is not an ontological category and spontaneous attribution of agency to physically unidentified sources is not counterintuitive (Atran 2002, 64-65), we have strong intuitions about personal agents. A humanlike agent that is not human is counterintuitive in the sense that some of its characteristic features violate panhuman intuitive expectations concerning personal agents, solid objects, and living things. A counterintuitive agent is anything that has (some of) the defining characteristics of a personal agent but yet somehow violates our intuitive expectations regarding agents. A person without a physical body is a counterintuitive agent; so is an artifact or a natural object that has agentive properties (see Boyer 2001, 51-93; Pyysiäinen 2001, 9-23; 2004b, 39-45; Pyysiäinen \& Lindeman \& Honkela 2003).

According to Boyer (1994; 2003a,b), counterintuitive agent representations are formed by adding a minor "tweak" to an intuitive agent representation. Such agent representations as ghosts, children's imaginary companions, fictional agents such as Mickey Mouse, and so forth, all are agents with some non-standard elements. It is thus unlikely that we have separate mental mechanisms for the construction of each type of agent representation. If this is so with ghosts and imaginary companions, then it is very likely that 
the same holds for gods. They are counterintuitive agents in the sense that their representation is carried out by the ordinary cognitive mechanisms, although some of their characteristics violate against panhuman intuitive expectations concerning persons. Yet the believers may find it quite natural that gods exist (cf. Barrett 2003).

There is also empirical evidence to support the hypothesis that the prefrontal system for processing agent causality tends to take over and interfere with folk-mechanical reasoning (see Wegner 2002, 26). Nielsen (1963), for example, showed in the 1960's that when subjects had to draw a straight line with their hand in a box and by looking into the box through a tube, they could be fooled into believing that the experimenter's hand seen in the box through a mirror was actually their own (which they did not see). When both hands followed a straight line, the subjects experienced the alien hand as their own. When the experimenter drew a curve to the right, the subjects still experienced the hand as their own, although now making involuntary movements.

Similarly, Ramachandran and colleagues arranged an experiment in which a subject with an arm amputation was asked to put his real arm and what was felt as a phantom limb in a box with a vertical mirror in the middle; the reflection of the real arm then appeared in the mirror where the phantom would be if it were real. When the subject moved the real arm, he experienced the phantom as moving voluntarily as well. Then the experimenter put his arm inside the box so that it appeared in the place of the phantom. Observing his real arm and the experimenter's arm in the box made the subject feel as though his phantom was moving (Ramachandran \& Blakeslee 1999, 46-48; see Wegner 2002, 40-44).

As Wegner (2002) argues, willful movement is an experience that follows from the convergence of observed movement and one's own thoughts. When action seems consistently to follow prior thought and when other apparent causes of action are excluded, we have the experience of volitional action. When we cannot control what happens, the control is attributed to some empirically unknown agent (see Wegner 2002, 221-270). Children, for 
example, tend to explain natural phenomena intentionally, favoring creationist-like arguments. Around the age of five they start to explain random events in nature as caused by invisible agents; only at 11 or 13 years of age did American children of non-fundamentalist homes begin to favor nonteleological explanations (Evans 2000; Kelemen 1999; 2004; Bering in press). Wegner $(2002,44)$ also suggests that the tendency to experience willful movement by watching any body move where one's own body ought to be, might be made possible by the mirror neuron system. Thus, religiosity in the sense of interaction with imagined (whether real or unreal) agents is made possible by the capacity of "mind-reading" and, possibly, by the mirror neuron system.

\section{Conclusion}

In this paper, I have not primarily tried to write a history of God in the Old Testament, to solve great theological or philosophical problems, or to examine all the arguments of the intelligent design camp; rather, I have tried to show what it actually is that is common in representations of Yahweh and the supposed intelligent designer of the cell, as well as in the many mediating counterintuitive agent representations. Although I have some constructive suggestions for the history of the Old Testament gods, philosophy of religion, and neocreationism, they are subservient to the general argument that as social constructs representations of gods are still constrained by the human psychological capacity of representing agency. What unites the various discourses on God is the natural human propensity to take recourse to agentive explanations whenever possible.

Here I do not try to explain how religion has originated, however. I am merely trying to show that once religion exists, the counterintuitive agent representations typifying it are mediated by the ordinary cognitive mechanisms of agent representation. No special, "religious" mechanisms are needed. It is possible, in principle, that religion emerges when some spontaneous counterintuitive agent representations become widespread and are adopted in social use (Boyer 2001); an alternative explanation is that 
religious practices exist in their own right, and that counterintuitive agent representations are then included in them for various contingent reasons.

Thus, I am not saying that god beliefs have arisen simply as automatic responses to the perception of ordered complexity. My claim is more in line with the Finnish tradition in the study of folk beliefs, in which it has been suggested that reported encounters with supernatural beings might be explained by the actualization of the traditional beliefs in certain circumstances that can be explained in terms of the psychology of perception (Honko 1991; Pentikäinen 1968). ${ }^{6}$ Even if we slightly naively assumed that the first idea of a god emerged when some of our remote ancestors were contemplating the apparent order and complexity of what they saw around them, we would still face the separate question of why and how this belief became widespread and why it has persisted to our day in so many different forms (see Barrett 2004, 41, 43; Pyysiäinen 2001, 217-225). It is not merely a question of the idea of god being triggered separately in individual minds by the perception of ordered complexity; people also communicate about gods and do things that imply a conscious reference to gods. Belief in god(s) is reinforced in many ways.

I would like to make two points with regard to this. First, the mental mechanisms for the detection and representation of agency form the necessary psychological basis for conceptions of gods. Second, god concepts therefore tend to be triggered by the same type of cues as agent representations in general. What is important is that these cues often trigger a somehow specified god concept; we do not enter various situations as blank slates and then react to a cue by activating a general concept of an agent. What is activated rather is the kind of concept of god one has learned in other contexts (see Pyysiäinen 2002, 123).

\footnotetext{
${ }^{6}$ Barrett $(2004,38-39)$ notes that, at least in most cases, belief in gods does not originate from perceptions of order and purpose in nature. The hyperactive agent detection device (HADD) merely reinforces beliefs about gods; it does not stimulate them. My emphasis is more on the fact that HADD does not automatically produce god concepts on the basis of perception of order and purpose. Yet such perception may well be more important in the generation of god concepts than what Barrett allows for.
} 
Thus there is a crucial difference between postulating agency to explain the behavior of moving marbles and the like and in believing that God controls the fates of humans. As an evolutionary adaptation, hyperactive agent detection is dependent on the ability to discard false positives effectively (Boyer 1996): if the strange sound in the grass turns out to be caused by the wind, one must be able to immediately discard the presumption that it was caused by some agent. The discussions of God I have analyzed testify to the simple fact that the idea of God is not easily discarded at all. People often (although not necessarily) persist in their religious beliefs come what may.

The stability of gods has two aspects, social and temporal. Representations of gods are shared by all or most members of a group, and they are long-lasting. This entails that belief in God is reinforced in communication: people do not merely believe in their own idiosyncratic agent representations but rather in what a significant reference group as a collective takes to be God. There is, for example, evidence that when our own perceptions contradict the majority view, we are prone to interpret our own perceptions according to the majority view (Asch 1956). We are often attracted to people who have attitudes similar to our own, and we tend to like people who share our beliefs, especially when we are temporarily confused or when the beliefs are unverifiable (Byrne \& Nelson \& Reeves 1966; Hinde 1999, 200). In addition, the repetition of a statement increases its likelihood of being regarded as true (Begg \& Anas \& Farinacci 1992). These are factors that certainly play a role in religion as well.

Although we make subjective intuitive inferences from the concept of 'God', we also publicly communicate about God, the views of others thus entertaining an influence on our own beliefs. It is not only cognition that moulds belief but more specifically social cognition. Cognitive processes mediate between a stimulus and a behavioral response but they are also sensitive to constraints of the social situation (see Bless \& Fiedler \& Strack 2004, 1-15, 119-43). Chwe (2001) argues that rituals (broadly conceived) create common, shared knowledge in the sense that people have beliefs 
and also beliefs about others' beliefs (and beliefs about others' beliefs about their beliefs, and so forth). Participation in common rituals enhances the implicit (or even explicit) belief that others have similar beliefs to one's own. However, it is not only the explicit communication of ideas that helps establish common knowledge; in rituals, people also engage in various kinds of motor actions, during which they both move themselves and watch others move (or even imitate others). Doing and imitating the doings of others, perhaps using the mirror neuron system, thus converge, creating a social experience that serves to strengthen common belief in the efficacy of rituals and the import of shared religious concepts and beliefs (see Pyysiäinen 2004b, 135-146; forthcoming).

In the Old Testament texts, we cannot know how various individuals have used representations of $\mathrm{El}$ or Yahweh to make inferences and predictions. However, to the extent that all representations of counterintuitive agents are produced and processed by the ordinary evolved mechanisms of mind, the basic cognitive processes underlying representations of $\mathrm{El}$, Yahweh, and so forth must have been the same as today; this is because evolved cognitive architecture cannot change in a mere 2,000 years (see Laland \& Brown 2002, 190-191). The various anthropomorphisms in the Old Testament lend support to the view that the psychological basis of the Christian concept of God is in the automatic and intuitive processes that produce agentive explanations for events and structures which manifest control and design.

In Old Testament religion, the most central idea is the covenant between Yahweh and the Israelites. It is constituted by the duties and privileges of each party, defined according to the model of the relationship between a king and his people; this, in turn, requires the mechanisms of social cognition. Yahweh thus becomes an interested party in human affairs. Although he might not be considered omniscient in the more or less literal sense discussed in modern theology, he obviously has what Boyer (2001, 150-167) calls "full access" to "strategic knowledge"; he has automatic access to all such information that triggers the reasoning mechanisms dedicated to the 
processing of information about agents. He may not know how many grains of sand there is in the desert but he certainly knows what A thinks about B's deeds as well as what B thinks A thinks about his or her deeds. God is a kind of supermind, or like a central unit in emulation of which individual human minds run like computer terminals (see Barrett \& Richert \& Driesenga 2001). As such, God is also the source of the norms and values in society; these are conceived of as the thoughts of God (Boyer 2002). The social order is thus reflected in the idea of God (see van der Toorn 1996, 181-372; also Anttonen 1996; 2000; Siikala 2002).

As the most important features of gods are often the counterintuitive features, it might be predicted that the more anthropomorphic features tend to be discarded whenever possible. Reflective thinking and the related external memory stores make this possible. In reflective thinking, the humanlike features are gradually removed from representations of God, thus making God more "transcendent" and by the same token also more powerful (see also Wiebe 1991). Unfortunately, it is not possible for humans to think about a completely different kind of being, stripped of from all anthropomorphisms (Ferré 1984). This problem was realized by Tillich, for example, when he argued that the personalistic features of God are at once problematic and necessary (and that therefore mediators are needed).

In this, Tillich is not alone, of course. Recently, this realization has received empirical support from Barrett and Keil's (1996) studies about the differing concepts of god (also Barrett 1998). When we explain this duality by dual-process theories, it should be noted that the theological concept of God also has a use, albeit a use that requires the special context of theology. As Barrett $(1998,617)$ says, the theological concept of God is a also concept; it is just more fragile and can be used to generate inferences only in sloweddown situations. It is a "cognitively assisted" concept in the sense that it is supported by various cultural institutions.

The theological concept of God is thus relatively impotent in everyday religiosity; the everyday concept, for its part, is unsatisfactory in theology. Yet theology cannot do without a connection to everyday religion, while 
everyday religion manages well without theology (Haavio 1959, 6; see Pyysiäinen 2004c). In theology, the concepts of everyday religion are analytically elaborated, without much attention being paid to their practical use in religion. Thus, much that makes everyday religion comprehensible and useful is simply discarded in theology (see Boyer 2001, 320-322). Despite this, theology receives its legitimation from religion, and theologians often tend to think that their conceptual elaborations are binding on people who should accommodate their behavior accordingly whenever possible (see Wiebe 1991). Here theology strongly differs from such paradigmatic examples of reflective thinking as mathematics and quantum theory.

In the philosophy of religion, the practical aspect of religion has been more strongly overlooked. Religious language has often been analyzed as so many conceptual problems, without any interest in its pragmatics. Such philosophizing has been criticized by, for example, continental philosophers of religion like Dalferth. In "Wittgensteinian" philosophy of religion, the real-life use of religious belief is used as a rhetorical argument, without any real attention being paid to what we actually know about religious behavior. Far-reaching conclusions are drawn largely on the basis of Wittgenstein's few remarks concerning afterlife and the last judgment (see Martin 1991). Finally, in ID neocreationism, God is implicitly or explicitly postulated as an explanation for the ordered complexity observed in nature, without any indication of how the designing has been done and how it could be scientifically studied.

What unites all these discourses is the fact that a feeling that there is order and control in what happens triggers representations of God, whether this is in ancient Israelite folk religion, theology and philosophy of religion, or scientific neocreationism. An increase in the understanding of the universe and its mysteries has always had, and continues to have, theological repercussions. This is because previously unknown natural mechanisms have repeatedly been substituted for the religious, agentive explanations. The repercussions are dealt with on two fronts: theologians (and philosophers) make adjustments in theological systems on the basis of new advances in 
the sciences, while some scientists (and philosophers), inspired by religion, try to introduce new concepts and principles in the sciences.

It is apparent, and not very surprising, that it is precisely evolutionary theory which is the touchstone in the debates between religion and science: this theory concerns not only some specific process or structure in reality but the general principles according to which all forms of life develop on earth, superceding all agentive explanations of this process in explanatory power (see Korthof 2004; Ruse 2003). Natural selection operating on random variation is a simple mechanism that explains the development of life with no need to bring beliefs and desires into the explanation.

In mainstream theologies, the apparent clash between religious agentexplanations and the mechanical explanations of science is usually explained away by saying that God is "behind" the facts that science helps us discover. No matter what new scientific discoveries are made, it is always possible to think that God is somehow "behind" it all. Evolution is only a mechanism, and God works by means of evolution. The ID scholars differ from theologians in that they have presented detailed biological and mathematical arguments in support of the claim that there must be an intelligent designer behind the universe. Modern theologians, however, want to avoid the embarrassing situation that the empirical arguments may some day be shown to be wrong, because then God beliefs should be abandoned, according to their own premises. Therefore, theologians are usually careful not to present any detailed scientific arguments. They talk about God, not about biology.

The cost of this move is that it becomes increasingly difficult to say how exactly God is supposed to interact with his creation. Origen's "simple believer" and a modern skeptic like Nielsen can both ask what it is that the theologian is really claiming. This questioning may then lead one of them to a more fundamentalist belief and the other to atheism. The theologian's answer may well be some kind of "Wittgensteinian" argument saying that religious claims are claims about religious claims. As the beliefs are not discarded, because they are embedded in the practices of everyday life (see Pyysiäinen 2001, 77-139; 2004b, 113-134), they must be reinterpreted so that agentive explanations are retained along with the scientific ones. 
Thus, once god concepts exist, perception of complexity and order can trigger them in whatever domain. We then have to evaluate rationally whether this is warranted in reflective thinking. This can lead to three different solutions. First, religion may be interpreted as a closed system either à la "Wittgensteinian fideism" or in the manner of Plantinga and others. Second, it may lead to questionable interpolations in scientific theories. Third, it may lead one to adopt an atheistic view. What ultimately unites these debates is the panhuman tendency to prefer agentive explanations to mechanistic ones, together with its collective reinforcement in religious practices.

Bibliography

\section{af Hällström, Gunnar}

1984 Fides simpliciorum according to Origen of Alexandria. Helsinki: Societas Scientiarum Fennica.

\section{Albright, William Foxwell}

1968 Yahweh and the gods of Canaan: A historical analysis of two contrasting faiths. London: Athlone Press.

\section{Alston, William P.}

1991 Perceiving God: The epistemology of religious experience. Ithaca, NY: Cornell University Press.

1994 Response to critics. - Religious Studies 30, 171-180.

\section{Anttonen, Veikko}

1996 Ihmisen ja maan rajat.[Corporeal and territorial boundaries]. Helsinki: SKS.

2000 Sacred. - Willi Braun \& Russell T. McCutcheon (eds), Guide to the Study of Religion, 271-282. London: Cassell.

\section{Aquinas, St. Thomas}

1962-63 Summa theologix I-III. Edited by Petri Caramello. Torino: Marietti.

\section{Asch, Solomon}

1956 Studies of independence and conformity: A minority of one against a unanimous majority. (Psychological Monographs; 70, No. 9.) New York: Columbia University. 


\section{Atran, Scott}

2002 In gods we trust: The evolutionary landscape of religion. Oxford: Oxford University Press.

\section{Augustinus, Aurelius}

1992 Confessions. Ed. by James J. O’Donnell. Oxford: Clarendon Press.

\section{Avikainen, Sari}

2003 Cortical mechanisms of action observation, imitation and social perception in healthy and autistic subjects. Unpublished MD thesis, University of Helsinki, Department of Neurology. PDF file available at: http: //ethesis.helsinki.fi/julkaisut/laa/kliin/vk/avikainen/cortical.pdf. [Accessed September 15, 2004.]

Ayer, Alfred Jules

1936 Language, truth, and logic. London: Gollancz.

\section{Baron-Cohen, Simon}

2000 The cognitive neuroscience of autism: Evolutionary approaches. - Michael S. Gazzaniga (ed.), The new cognitive neurosciences, 1249-1257. Cambridge, MA: MIT Press.

\section{Barrett, Justin L.}

1998 Cognitive constraints on Hindu concepts of the divine. - Journal for the Scientific Study of Religion 37, 608-619.

1999 Theological correctness: Cognitive constraint and the study of religion. - Method E Theory in the Study of Religion 11, 325-339.

2000 Exploring the natural foundations of religion. - Trends in Cognitive Sciences 4, 29-34.

2003 Epidemiological and nativist accounts in the cognitive study of culture: A commentary on Pyysiäinen's innate fear of Bering's ghosts. - Journal of Cognition and Culture 3(3), 226-232.

2004 Why would anyone believe in God? Walnut Creek, CA: AltaMira Press.

\section{Barrett, Justin L. \& Frank Keil}

1996 Conceptualizing a nonnatural entity: Anthropomorphism in God concepts. - Cognitive Psychology 31, 219-247.

\section{Barrett, Justin L. \& Rebekah A. Richert \& Amanda Driesenga}

2001 God's beliefs versus mothers: The development of nonhuman agent concepts. - Child Development 72(1), 50-65.

\section{Barrett, Justin L. \& Amanda Hankes Johnson}

2003 The role of control in attributing intentional agency to inanimate objects. - Journal of Cognition and Culture 3(3), 208-217.

\section{Begg, Ian Maynard \& Ann Anas \& Suzanne Farinacci}

1992 Dissociation of processes in belief: Source recollection, statement fa- 
miliarity, and the illusion of truth. - Journal of Experimental Psychology: General 121(4), 446-458.

Behe, Michael J.

1996 Darwin's black box: The biochemical challenge to evolution. New York: Free Press.

\section{Bering, Jesse}

In press. The evolutionary history of an illusion: Religious causal beliefs in children and adults. - D. Ellis \& D.F. Bjorklund (eds), Origins of the social mind: Evolutionary Psychology and child development. New York Guilford Press.

Blakemore, S.-J. \& P. Boyer \& M. Pachot-Clouard \& A. Meltzoff \& C. Segerbarth \& Decety, J.

2003 The detection of contingency and animacy from simple animations in the human brain. - Cerebral Cortex 13, 837-844.

\section{Bless, Herbert \& Klaus Fiedler \& Fritz Strack}

2004 Social cognition: How individuals construct social reality. Hove, UK: Psychology Press.

\section{Boyer, Pascal}

1994 The naturalness of religious ideas: A cognitive theory of religion. Berkeley: University of California Press.

1996 What makes anthropomorphism natural: Intuitive ontology and cultural representations. - The Journal of the Royal Anthropological Institute n.s. 2, 83-97.

2000 Functional origins of religious concepts: Ontological and strategic selection in evolved minds. - The Journal of the Royal Anthropological Institute n.s. 6, 195-214.

2001 Religion explained. New York: Basic Books.

2002 Why do gods and spirits matter at all? - Ilkka Pyysiäinen \& Veikko Anttonen (eds), Current approaches in the cognitive science of religion, 68-92. London: Continuum.

2003a Religious thought and behaviour as by-products of brain function. - Trends in Cognitive Sciences 7(3), 119-124.

2003b Are ghost concepts "intuitive," "endemic" and "innate"? - Journal of Cognition and Culture 3(3), 233-243.

\section{Boyer, Pascal \& Harold C. Barrett}

In press. Evolved intuitive ontology: Integrating neural, behavioural and developmental aspects of domain-specificity. - David Buss (ed.), Handbook of evolutionary psychology. Indianapolis: Wiley.

Bremmer, F. \& A. Schlack \& N.J. Shah \& O. Zafiris \& M. Kubischik \& K.-P. Hoffmann \& K. Zilles \& G.R. Fink

2001 Polymodal motion processing in posterior parietal and premotor 
cortex: A human fMRI study strongly implies equivalencies between humans and monkeys. - Neuron 29, 287-296.

\section{Byrne, Donn \& Don Nelson \& Keith Reeves}

1966 Effects of consensual validation and invalidation on attraction as a function of verifiability. - Journal of Experimental Social Psychology 2, 98-107.

Carruthers, Peter \& Peter K. Smith (eds)

1996 Theories of theories of mind. Cambridge: Cambridge University Press.

Chadwick, Henry

1966 Early Christian thought and the classical tradition. Oxford: Clarendon Press.

Charlesworth, M.J.

1972 Philosophy of religion: The historic approaches. London: Macmillan.

\section{Chwe, Michael Suk-Young}

2001 Rational ritual: Culture, coordination, and common knowledge. Princeton: Princeton University Press.

\section{Craig, William Lane}

1979 The Kalâm cosmological argument. London: Macmillan.

\section{Craig, William Lane \& Quentin Smith}

1995 (1993) Theism, atheism and big bang cosmology. Oxford: Clarendon Press.

Cross, Frank M. Jr.

1961 The development of the Jewish scripts. - Ernest G. Wright (ed.), The Bible and the ancient Near East: Essays in honor of William Foxwell A bright, 133-202. London: Routledge.

\section{Cruse, Holk}

2003 The evolution of cognition - a hypothesis. - Cognitive Science 27, 135155.

\section{Csibra, György}

2003 Teleological and referential understanding of action in infancy. - Philosophical Transactions of the Royal Society, London, B 358, 447-458.

\section{Csibra, G. \& G. Gergely \& S. Bíró \& O. Kóós \& M. Brockbank}

1999 Goal attribution without agency cues: The perception of 'pure reason' in infancy. - Cognition 72, 237-267.

Dalferth, Ingolf Ulrich

1981 Religiöse Rede von Gott. München: Kaiser. 


\section{Deacon, T.W.}

1998/1997 The symbolic species: The co-evolution of language and the brain. New York: Norton.

\section{Di Vito, Robert A.}

1993 Studies in third millennium Sumerian and Akkadian personal names: The designation and conception of the personal god. (Studia Pohl: Series Maior; 16.) Roma. Pontificio Istituto Biblico.

\section{Edis, Taner}

2002 The ghost in the universe: God in light of modern science. Amherst, NY: Prometheus Books.

2004a Grand themes, narrow constituency. - Matt Young \& Taner Edis (eds), Why intelligent design fails, 9-19. New Brunswick: Rutgers University Press.

2004b Chance and necessity - and intelligent design? - Matt Young \& Taner Edis (eds), Why intelligent design fails, 139-152. New Brunswick: Rutgers University Press.

\section{Evans, Jonathan St. B.T.}

2003 In two minds: Dual-process accounts of reasoning. - Trends in Cognitive Sciences 7(10), 454-459.

\section{Evans, Margaret}

2000 Beyond scopes: Why creationism is here to stay. - Karl S. Rosengren \& Carl N. Johnson, \& Paul L. Harris (eds), Imagining the impossible: Magical, scientific, and religious thinking in children, 305-333. Cambridge: Cambridge University Press.

\section{Ferré, Frederick}

1967 Basic modern philosophy of religion. New York: Charles Scriebner's Sons.

1984 In praise of anthropomorphism. - International Journal for the Philosophy of Religion 16, 203-212.

\section{Flew, Antony}

1972 (1955) Theology and falsification A \& B. - Antony Flew \& Alasdair MacIntyre (eds), New essays in philosophical theology, 96-99, 106-108. London: SCM Press.

Flew, Antony, \& Alasdair MacIntyre (eds) 1972 (1955) New essays in philosophical theology. London: SCM Press.

\section{Fitch, W. Tecumseh, \& Mark D. Hauser}

2004 Computational constraints on syntactic processing in a nonhuman primate. - Science 303, 377-380.

\section{Fodor, Jerry A.}

1975 The language of thought. Cambridge, MA: Harvard University Press. 
Frith, Uta

2001 Mind blindness and the brain in autism. - Neuron 32, 969-979.

Fuster, J.

2002 Frontal lobe and cognitive development. - Journal of Neurocytology 31(3-5), 373-385.

Gallagher, Helen L. \& Christopher D. Frith

2003 Functional imaging of 'theory of mind'. - Trends in Cognitive Sciences 7(2), 77-83.

Gallese, Vittorio \& Christian Keysers \& Giacomo Rizzolatti

2004 A unifying view of the basis of social cognition. - Trends in Cognitive Sciences 8(9), 396-403.

Gallese, Vittorio \& Thomas Metzinger

2003 Motor ontology: The representational reality of goals, actions and selves. - Philosophical Psychology 16(3), 365-388.

Gallese, Vittorio \& L. Fadiga \& L. Fogassi \& G. Rizzolatti

1996 Action recognition in the premotor cortex. - Brain 119, 593-609.

Gallese, Vittorio \& A. Goldman

1998 Mirror neurons and the simulation theory of mind-reading. - Trends in Cognitive Sciences 12, 493-501.

Gauthier, Léon

1948 Ibn Rochd (Averroës). Paris: Presses universitaires.

Gergely, György \& Gergely Csibra

2003 Teleological reasoning in fancy: The naïve theory of rational action. - Trends in Cognitive Sciences 7, 287-292.

Giles, Jim

2004 Peer-reviewed paper defends theory of intelligent design. - Nature 431 (9 September), 114.

Gnuse, Robert K.

2000 The Old Testament and process theology. St. Louis, Missouri: Chalice press.

Goody, Jack

2000 The power of the written tradition. Washington: Smithsonian Institution Press.

Guthrie, Stewart

1993 Faces in the clouds. New York: Oxford University Press. 


\section{Haavio, Martti}

1959 Karjalan jumalat [Karelian gods]. Helsinki: WSOY.

Hari, R. \& N. Forss \& S. Avikainen \& S. Kirveskari \& S. Salenius \& G. Rizzolatti

1998 Activation of human primary motor cortex during action observation: A neuromagnetic study. - Proceedings of the National Academy of Sciences USA 95, 15,061-15,065.

\section{Heider, Fritz \& Mary-Ann Simmel}

1944 An experimental study of apparent behavior. - American Journal of Psychology 57, 243-249.

\section{Hinde, Robert A.}

1999 Why gods persist: A scientific approach to religion. London: Routledge.

\section{Honko, Lauri}

1991 (1962) Geisterglaube in Ingermanland, Vol. I. (FF Communications 185.) Helsinki: Academia Scientiarum Fennica.

\section{Hurd, Gary S.}

2004 The explanatory filter, archaeology, and forensics. - Matt Young \& Taner Edis (eds), Why intelligent design fails, 107-120. New Brunswick: Rutgers University Press.

\section{Kelemen, Deborah}

1999 Why are rocks pointy? Children's preference for teleological explanations of the natural world. - Developmental Psychology 35, 1440-1453.

2004 Are children "intuitive theists"? Reasoning about purpose and design in nature. - Psychological Science 15(5), 295-301.

\section{Kenney, John Peter}

1991 Mystical monotheism: A study in Ancient Platonic theology. Hanover: Brown University Press.

\section{Kenny, Anthony}

1979 The God of the philosophers. Oxford: Clarendon Press.

\section{Knuuttila, Simo}

1993a Modalities in Medieval philosophy. London: Routledge.

1993b Trinitarian sophisms in Robert Holcott's theology. - S. Read (ed.), Sophisms in Medieval logic and grammar, 348-356. Dordrecht: Kluwer.

\section{Korthof, Gert}

2004 Common descent: It's all or nothing. - Matt Young \& Taner Edis (eds), Why intelligent design fails, 32-47. New Brunswick: Rutgers University Press. 


\section{Lakoff, George \& Rafael E. Núñez}

2000 Where mathematics comes from. New York: Basic Books.

\section{Laland, Kevin N. \& Gillian Brown}

2002 Sense and nonsense: Evolutionary perspectives on human behavior. Oxford: Oxford University Press.

\section{Lauha, Risto}

1997 Jahve-monoteismin synty ja kehitys [The birth and development of Yahweh-monotheism]. - Teologinen Aikakauskirja 102(2), 126-133.

\section{Lawson, E. Thomas}

2001 Psychological perspectives on agency. - Jensine Andresen (ed.), Religion in mind: Cognitive perspectives on religious belief, ritual and experience, 141-172. Cambridge: Cambridge University Press.

Leslie, Alan

1994 ToMM, ToBy, and agency: Core architecture and domain specificity. - Lawrence Hirschfeld \& Susan Gelman (eds), Mapping the mind, 119-148. Cambridge: Cambridge University Press.

1996 (1995) A theory of agency. - Dan Sperber \& David Premack \& Ann J. Premack (eds), Causal cognition, 121-141. Oxford: Clarendon Press.

\section{Leslie, Alan M. \& Ori Friedman \& Tim German}

2004 Core mechanisms in 'theory of mind'. - Trends in Cognitive Sciences $8(12), 528-533$

\section{Lieberman, M. D. \& R. Gaunt \& D. T. Gilbert \& Y. Trope}

2002 Reflexion and reflection: A social cognitive neuroscience approach to attributional inference. - Advances in Experimental Social Psychology 34, 199-249.

\section{Malley, Brian}

2004 How the Bible works: An anthropological study of evangelical Biblicism. Walnut Creek, CA: AltaMira Press.

\section{Martin, Luther $\mathbf{H}$.}

2004 Towards a cognitive history of religions. - Christoph Kleine \& Monika Schrimpf \& Katja Triplett (eds), Unterwegs. Neue Pfade in der Religionswissenschaft / New Paths in the Study of Religions: Festschrift for Michael Pye. München: Biblion.

In press. Performativity, narrativity, and cognition: 'Demythologizing' the Roman Cult of Mithras. - Willi Braun (ed.), Persuasion and performance: Rhetoric and reality in early Christian discourses. Waterloo: Wilfrid Laurier University Press.

\section{Martin, Michael}

1990 Atheism: A philosophical justification. Philadelphia: Temple University Press. 
1991 Wittgenstein's lectures on religious belief. - Heythrop Journal 32, 369-382.

Meyer, Stephen .C.

2004 The origin of biological information and the higher taxonomic categories. - Proceedings of the Biological Society of Washington 117(2), 213-239. Republished online August 28, 2004 at: http://www.discovery.org/ scripts/viewDB/index.php?command=view\& id=2177. [Accessed September 24, 2004.]

\section{Mithen, Steven}

2004 From Ohalo to Çatalhöyük: The development of religiosity during the early prehistory of Western Asia, 20,000-7000 BC. - Harvey Whitehouse \& Luther H. Martin (eds), Theorizing religions past: Archaeology, History, and Cognition, 173-194. Walnut Creek, CA: AltaMira Press.

\section{Munz, Peter}

1959 Problems of religious knowledge. London: SCM Press.

\section{Musgrave, Ian}

2004 Evolution of the bacterial flagellum. - Matt Young \& Taner Edis (eds), Why intelligent design fails, 72-84. New Brunswick: Rutgers University Press.

\section{Nagao, Gadjin}

1992 (1991) Mâdhyamika and Yogâcâra. Ed. \& tr. by Leslie S. Kawamura. Delhi: Satguru Publications.

\section{Niditch, Susan}

1996 Oral and written word: Ancient Israelite literature. Louisville, KY: Westminster/John Knox.

\section{Nielsen, Kai}

1985 Philosophy $\mathcal{E}$ atheism: In defense of atheism. Buffalo, NY: Prometheus Books.

1989 God, scepticism and modernity. Ottawa: University of Ottawa Press.

\section{Nielsen, T.I.}

1963 Volition: A new experimental approach. - Scandinavian Journal of Psychology 4, 225-230.

\section{Ockham, William}

1991 Quodlibetal questions, vol. I. Tr. by Alfred J. Freddoso \& Francis E. Kelly. New Haven, Conn.: Yale University Press.

\section{Pentikäinen, Juha}

1968 The Nordic dead-child tradition. Tr. by Anthony Landon. (FF Communications 202.) Helsinki: Academia Scientiarum Fennica. 


\section{Perakh, Mark}

2004 There is a free lunch after all: William Dembski's wrong answers to irrelevant questions. - Matt Young \& Taner Edis (eds), Why intelligent design fails, 153-171. New Brunswick: Rutgers University Press.

\section{Perakh, Mark \& Matt Young}

2004 Is intelligent design science? - Matt Young \& Taner Edis (eds), Why intelligent design fails, 185-196. New Brunswick: Rutgers University Press.

Person, Raymond F. Jr.

1998 The ancient Israelite scribe as performer. - Journal of Biblical Literature 117(4), 601-609.

Phillips, D.Z.

1976 Religion without explanation. Oxford: Basil Blackwell.

1988 Faith after foundationalism. London: Routledge.

2000 Recovering religious concepts: Closing epistemic divides. London: Macmillan.

\section{Philo Alexandrianus}

1991 (1929) De opificio mundi. Philo, Vol. I, tr. \& ed. by F.H. Colson and G.H. Whitaker. (Loeb Classical Library.) Cambridge, MA: Harvard University Press.

1991 (1929). Legum allegoriae. Philo, Vol. I, tr. \& ed. by F.H. Colson and G.H. Whitaker. (Loeb Classical Library.) Cambridge, MA: Harvard University Press.

\section{Pihlström, Sami}

2002 Pragmatic and transcendental arguments for theism: A critical examination. - International Journal for Philosophy of Religion 51, 195-213.

\section{Plantinga, Alvin}

1990 God and other minds: A study of the rational justification of belief in God. Ithaca, NY: Cornell University Press.

\section{Plantinga, Alvin (ed.)}

1968 (1965) The ontological argument. London: Macmillan.

\section{Polkinghorne, John}

1998 Belief in God in an age of science. New Haven, Conn: Yale University Press.

\section{Premack, David}

1990 The infant's theory of self-propelled objects. - Cognition 36, 1-16.

Premack, David \& Ann Premack

2002 Original intelligence. New York: McGraw-Hill. 


\section{Pyysiäinen, Ilkka}

1996 Jñânagarbha and the God's-eye view. - Asian Philosophy 6, 197-206.

1997 Jumalan selitys [God explained]. Helsinki: Otava.

2001 How religion works: Towards a new cognitive science of religion. Leiden: Brill.

2002 Religion and the counter-intuitive. - Ilkka Pyysiäinen \& Veikko Anttonen (eds), Current approaches in the cognitive science of religion, 111-133. London: Continuum.

2003a Buddhism, religion, and the concept of 'god'. - Numen 50(2), 147171.

2003b Dual-process theories and hybrid systems: A commentary on Anderson \& Lebiere. - Behavioral and Brain Sciences 26(5), 617-618.

2004a Intuitive and explicit in religious thought. - Journal of Cognition and Culture 4(1), 123-151.

2004b Magic, miracles, and religion: A scientist's perspective. Walnut Creek: AltaMira Press.

2004c Folk religion and theological correctness. - Temenos 39-40, 151-165.

Forthcoming. Believing and doing: How ritual action enhances religious belief. Paper under submission.

\section{Pyysiäinen, Ilkka \& Kimmo Ketola}

1999 Rethinking 'god': 'God' as category in comparative religion. - Tore Ahlbäck (ed.), Approaching religion, part 1, (Scripta Instituti Donneriani Aboensi:, 17:1), 207-214. Abo: The Donner Institute.

\section{Pyysiäinen, Ilkka \& Marjaana Lindeman \& Timo Honkela}

2003 Counterintuitiveness as the hallmark of religiosity. - Religion 33(4), 341-355.

\section{Pyysiäinen, Ilkka \& Veikko Anttonen (eds)}

2002 Current approaches in the cognitive science of religion. London: Continuum.

\section{Räisänen, Heikki}

2000 (1990) Beyond New Testament theology. London: SCM Press.

\section{Ramachandran, Vilayanur S. \& Sandra Blakeslee}

1999 (1998) Phantoms in the brain. New York: Quill, William Morrow.

\section{Rizzolatti, G. \& M.A. Arbib}

1998 Language within our grasp. - Trends in Neurosciences 21, 188-194.

\footnotetext{
Rizzolatti, G. \& R. Camarda \& L. Fogassi \& M. Gentilucci \& G. Luppino \& M. Matelli

1988 Functional organization of inferior area 6 in the macaque monkey: II: Area F5 and the control of distal movements. - Experimental Brain Research 71, 491-507.
} 
Rizzolatti, G. \& L. Fogassi \& V. Gallese

2000 Cortical mechanisms subserving object grasping and action recognition: A new view on the cortical motor functions. - M. Gazzaniga (ed.), The cognitive neurosciences, 539-552. Cambridge, MA: MIT Press.

Ruse, Michael

2003 Darwin and design. Cambridge, MA: Harvard University Press.

\section{Schopenhauer, Arthur}

1947 Parerga und paralipomena, zweiter Band. Sämtliche Werke 6. Wiesbaden: Brockhaus.

Shallit, Jeffrey \& Wesley Elsberry

2004 Playing games with probability: Dembski's Complex specified information. - Matt Young \&Taner Edis (eds), Why intelligent design fails, 121-138. New Brunswick: Rutgers University Press.

\section{Siikala, Anna-Leena}

2002 Mythic images and shamanism. (FF Communications 280.) Helsinki: Academia Scientiarum Fennica.

Sloman, S.A.

1996 The empirical case for two systems of reasoning. - Psychological Bulletin 119(1), 3-22.

Smith, Mark S.

2002 (1990) The early history of God. Grand Rapids, MI: Eerdmans.

2001 The origins of biblical monotheism: Israel's polytheistic background and the Ugaritic texts. New York: Oxford University Press.

\section{Sperber, Dan}

1995 (1974) Rethinking symbolism. Cambridge: Cambridge University Press.

1996 Explaining culture: A naturalistic approach. Oxford: Blackwell.

\section{Stokes, Trevor}

2004 Intelligent design study appears. - The Scientist, September 3, 2004. http://www.the-scientist.com/2004/09/3. [Accessed September 24, 2004.]

\section{Stump, Eleonore \& Michael J. Murray}

1999 Philosophy of religion: The big questions. Malden, MA: Blackwell.

Taliaferro, Charles \& Paul J. Griffiths (eds)

2003 Philosophy of religion: An anthology. Malden, MA: Blackwell.

Tennant, F.R.

1968 (1928-30) Philosophical theology, I-II. Cambridge: Cambridge University Press. 


\section{Tillich, Paul}

1967 (1951, 1957, 1963) Systematic theology I-III. Chicago: University of Chicago Press.

\section{Tomasello, M. \& J. Call \& B. Hare}

2003 Chimpanzees understand psychological states - the question is which ones and to what extent. - Trends in Cognitive Sciences 7(4), 153-156.

\section{Ussery, David}

2004 Darwin's transparent box: The biochemical evidence for evolution. - Matt Young \& Taner Edis (eds), Why intelligent design fails, 48-57. New Brunswick: Rutgers University Press.

van der Toorn, $\mathrm{K}$.

1996 Family religion in Babylonia, Syria \& Israel. (Studies in the History and Culture of the Ancient Near East; VII.) Leiden: Brill.

\section{Wegner, Daniel M.}

2002 The illusion of conscious will. Cambridge, MA: MIT Press.

\section{Whitehouse, Harvey}

2000 Arguments and icons: Divergent modes of religiosity. Oxford: Oxford University Press.

2004 Modes of religiosity: A cognitive theory of religious transmission. Walnut Creek, CA: AltaMira Press.

Whitehouse, Harvey \& Luther H. Martin (eds)

2004 Theorizing religions past: Archaeology, History, and Cognition. Walnut Creek, CA: AltaMira Press.

\section{Wiebe, Donald}

1991 The irony of theology and the nature of religious thought. Montreal: McGill-Queen's University Press.

\section{Wisdom, John}

1944 Gods. - Proceedings of the Aristotelian Society 45, 185-206.

\section{Wittgenstein, Ludvig}

1966 (1938) Lectures and conversations on aesthetics, psychology and religious belief. Oxford: Basil Blackwell.

\section{Wolfson, Harry Austryn}

1948 (1947) Philo: Foundations of religious philosophy in Judaism, Christianity, and Islam. Cambridge, MA: Harvard University Press.

1959 The philosophical implications of the problem of divine attributes in the Kalam. - Journal of the American Oriental Society 79(2), 73-80.

1961 Religious philosophy. Cambridge, MA: The Belknap Press of Harvard University Press. 
Würthwein, Ernst

1987 (1979) The text of the Old Testament. Tr. by Erroll F. Rhodes. Grand Rapids, MI: Eerdmans.

Yandell, Keith E.

1999 Philosophy of religion: A contemporary introduction. London: Routledge.

Young, Matt

2004 Grand designs and facile analogies: Exposing Behe's mousetrap and Dembski's arrow. - Matt Young \& Taner Edis (eds), Why intelligent design fails, 20-31. New Brunswick: Rutgers University Press.

Young, Matt \& Taner Edis

2004 Introduction. - Matt Young \& Taner Edis (eds), Why intelligent design fails, 1-8. New Brunswick: Rutgers University Press. 